\title{
Benthic metabolism and sulfate reduction in a southeast Asian mangrove swamp
}

\author{
Erik Kristensen ${ }^{1}$, Marianne Holmer ${ }^{1}$, Nipavan Bussarawit ${ }^{2}$ \\ ${ }^{1}$ Institute of Biology, Odense University, DK-5230 Odense M, Denmark \\ ${ }^{2}$ Phuket Marine Biological Center, PO Box 60, Phuket, 83000 Thailand
}

\begin{abstract}
Sediment metabolism (surface $\mathrm{O}_{2}$ uptake and $\mathrm{CO}_{2}$ production) and ${ }^{35} \mathrm{~S}_{-} \mathrm{SO}_{4}{ }^{2-}$ reduction $(0$ to $10 \mathrm{~cm}$ ) were measured during January 1990 (dry season) at 3 stations in the Ao Nam Bor mangrove, Phuket, Thailand. Sulfate reduction as measured by the chromium reduction technique was highest at 6 to $10 \mathrm{~cm}$ depth at all stations ( 600 to $800 \mathrm{nmol} \mathrm{S} \mathrm{cm} \mathrm{d}^{-3}$ ), indicating that significant activity may have occurred below $10 \mathrm{~cm}$. Vertical translocation of metabolizable organic substrates, either due to subsurface root growth or due to downward transport of newly deposited organic matter by bioturbation appeared responsible for the high subsurface activity. The major reduced sulfur compound at all 3 stations was $\mathrm{FeS}_{2}$, both as recovered ${ }^{35} \mathrm{~S}$-label in the sulfate reduction assay ( 82 to $97 \%$ ) and in the total sediment sulfur pool ( 86 to $100 \%$ ). Very low amounts of reduced sulfur were found as $\mathrm{HS}^{-}$, FeS and $\mathrm{S}^{\circ}$. The general absence of $\mathrm{HS}^{-}$was caused by precipitation reactions controlled by a large sedimentary iron pool. The estimated areal based rates of sulfate reduction $\left(0\right.$ to $10 \mathrm{~cm}, 28$ to $\left.50 \mathrm{mmol} \mathrm{m}{ }^{-2} \mathrm{~d}^{-1}\right)$ could support around $100 \%$ (65 to $142 \%$ ) of the measured $\mathrm{CO}_{2}$ flux across the sediment-water interface. This implies a deficient or non-steady state $\mathrm{CO}_{2}$ flux since the sulfate reduction estimate ignored any activity occurring below $10 \mathrm{~cm}$ depth. Possible causes for this deficit may include $\mathrm{CO}_{2}$ assimilation by roots, advective loss of pore water $\mathrm{CO}_{2}$, and excessive $\mathrm{CO}_{2}$ gas loss during air exposure. In general, the mechanisms underlying carbon and sulfur cycling in this mangrove swamp appears remarkably similar to those operating in salt marshes.
\end{abstract}

\section{INTRODUCTION}

Mangrove swamps occupy a considerable part of tropical and subtropical coastlines, reaching their greatest extent in southeast Asia. They are, along with salt marshes, one of the most productive ecosystems in the world and support highly developed detritus-based food webs (Odum \& Heald 1975, Robertson 1986). Organic detritus produced in mangrove swamps will either be degraded and recycled in the sediments or exported to adjacent areas (Woodroffe 1985, Robertson 1986, Twilley et al. 1986, Kristensen et al. 1988). Although the abundant mangrove crab fauna is believed to consume significant amounts of leaf litter as a major portion of their diet (Robertson 1986, Neilson \& Richards 1989), decomposition of mangrove detritus is essentially a microbially mediated process (Alongi 1989). Several reports have dealt with aspects of degradation of mangrove detritus such as litter bag studies (Boonruang 1978, Cundell et al. 1979, Rice \& Tenore 1981), dissolved organic matter/bacteria interactions (Benner et al. 1986, Gonzalez-Farias \& Mee 1988, Boto et al, 1989), microbial distribution, and standing stocks and community structure (Alongi 1989). However, no studies have directly measured rates of the important anaerobic mineralization process, sulfate reduction, in tropical mangrove sediments. This, and the fact that the few published studies on mangrove energy and element cycling have been performed in North America and Australia, emphasize the need for further investigations especially in the mangroves of southeast Asia.

In salt marshes, the ecological equivalent of mangroves in temperate areas, sulfate reduction is known to be the major mineralization process (Howarth \& Teal 1979, Howarth \& Hobbie 1982, Howarth 1984, King et al. 1985, Mackin \& Swider 1989). The large inputs of organic matter support high rates of heterotrophic metabolism. Since oxygen is usually depleted below a few mm depth, even where the sediment surface is exposed to air, anaerobic metabolism predominates with decomposition mediated primarily by fermentative and sulfate-reducing bacteria (Howarth \& Teal 1979, Jørgensen 1983, King 1988). 
Sulfide formed as the product of bacterial sulfate reduction usually undergoes rapid diagenetıc transformations in coastal sediments. Hydrogen sulfide may readily precipitate with $\mathrm{Fe}^{2+}$ to form iron sulfides. The exact oxidation/reduction transformations involving varlous reduced sulfur pools in sediments are not yet fully understood. Most sedimentary sulfide is usually recovered as acid volatile sulfur (AVS $\approx \mathrm{H}_{2} \mathrm{~S}+\mathrm{FeS}$ ) and chromium reducible sulfur ( $C R S \approx \mathrm{S}^{\circ}+\mathrm{FeS}_{2}$ ) pools (Fossing \& Jørgensen 1989, Thode-Andersen \& Jørgensen 1989).

The purpose of the present study was to quantify bacterial sulfate reduction in 3 sediments of the southeast Asian mangrove swamp, Ao Nam Bor, by the use of a recently developed ${ }^{35} \mathrm{~S}$ radiotracer technique (Fossing \& Jørgensen 1989). The partitioning of reduced inorganic sulfur compounds into varnous reduced pools was assessed, both as recovered ${ }^{35} \mathrm{~S}$-label and in the total sediment pool. Estımated depth-integrated rates of sulfate reduction and measured fluxes of $\mathrm{O}_{2}$ and $\mathrm{CO}_{2}$ across the sediment water interface were evaluated and discussed in relation to physical disturbances and transport processes in the sediment

\section{MATERIALS AND METHODS}

Study site. The study was conducted during January 1990 (dry season) in the Ao Nam Bor mangrove about $5 \mathrm{~km}$ north of Phuket Marine Brological Center on the southeast coast of Phuket Island, Thailand (Fig.1). The mangrove swamp is about $300 \mathrm{~m}$ wide from inland to

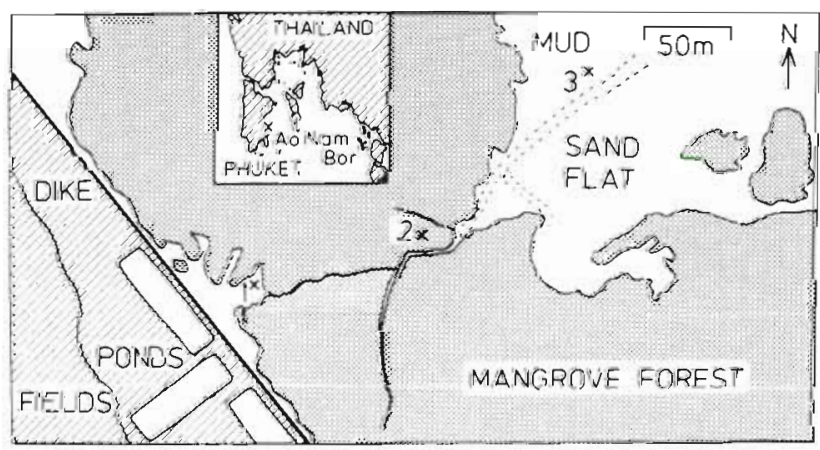

Fig 1 Ao Nam Bor mangrove $\left(98^{\circ} 25^{\prime} \mathrm{E}, 7^{\circ} 51^{\prime} \mathrm{N}\right)$ showing the location of sampling Stns 1 to 3

seaward edge at the study site. The landward fringe is separated from newly established shrump ponds by a $1.5 \mathrm{~m}$ high dike. Tidal creeks that lead all the way through this Rhizophora apiculata dominated mangrove forest drain into a wide $(0.5$ to $1 \mathrm{~km})$ vegetationfree sand-and mudflat The mangrove is almost completely tidally dominated with freshwater input occurring only during heavy rain periods. Tidal range in the area is ca $2 \mathrm{~m}$, but the inner mudflat is usually not covered by more than $1 \mathrm{~m}$ during high tide. During spring tides the landward fringe is inundated for only about $2 \mathrm{~h}$ (max. water depth ca $0.3 \mathrm{~m}$ ), while the mudflat is flooded for about 6 h per tidal cycle. Salinity and water temperature during January are 33 to $35 \%$ S and 28 to $33^{\circ} \mathrm{C}$, respectively. A detailed description of the study site is given by Frith et al. (1976) and Limpsalchol (1978).

Three stations were established in the Ao Nam Bor area: Stn 1, close to the landward fringe on a nonvegetated bank adjacent to a small ca $1 \mathrm{~m}$ wide creek (Zone 2 of Fnth et al. 1976); Stn 2, within the mangrove forest between prop' roots of Rhizophora apiculata ca $30 \mathrm{~m}$ from the seaward fringe and ca $15 \mathrm{~m}$ from a $4 \mathrm{~m}$ wide creek (Subzone 3b of Frith et al. 1976; SUN Stn of Kristensen et al. 1988); and Stn 3 on the mudflat ca $100 \mathrm{~m}$ outside the forest (Zone 6 of Frith et al. 1976).

Sampling procedures. Sediment cores for solid phase analysis, pore water extractions and redox (Eh) measurements were sampled with $5.2 \mathrm{~cm}$ i.d. acrylic core tubes. Cores for flux incubations as well as those for determination of macrofaunal density were taken with $8.0 \mathrm{~cm}$ i.d. tubes while $2.6 \mathrm{~cm}$ i.d. tubes were used for the measurement of sulfate reduction, inorganic sulfur pools and $\mathrm{pH}$. Cores were sampled by hand at low tide during daytime. All laboratory treatments were initiated within $2 \mathrm{~h}$ after sampling. Sediment for solid phase, pore water and sulfate reduction analysis were sectioned into $0-1,1-2,2-3,3-4,4-6,6-8,8-10$ $\mathrm{cm}$ depth intervals. Most attempts to sample deeper cores falled due to the presence of large roots and stones below 15 to $20 \mathrm{~cm}$. The density of major faunal species were estimated from the number of animals collected after sieving 5 to 10 cores $\left(64 \mathrm{~cm}^{2}\right.$ each) per station through a $1.5 \mathrm{~mm}$ mesh.

Sediment characteristics. Porosity was calculated from water loss of a known sediment volume after drying at $100^{\circ} \mathrm{C}$ for $12 \mathrm{~h}$. Organic content was measured on dried and ground sediment samples as loss-onignition (LOI) at $520^{\circ} \mathrm{C}$ for $6 \mathrm{~h}$ and as particulate organic carbon (POC) and nitrogen (PON) as described by Krustensen \& Andersen (1987). POC and PON were analysed on a Hewlett-Packard 185B CHN Analyzer.

Pore water. Pore water was obtained from 3 replicate cores by centrifuging 1 to $2 \mathrm{~cm}$ sediment sections for 5 to $10 \mathrm{~min}$ at $2000 \mathrm{rpm}$. Samples for $\mathrm{SO}_{4}^{2-}$ analysis were immediately acldified with concentrated $\mathrm{HCl}$ to ca $\mathrm{pH} 2$ and kept refrigerated $\left(4^{\circ} \mathrm{C}\right)$ until analysis with a Kontron Ion Liquid Chromatograph. Samples for measurement of free sulfide were fixed in $20 \% \mathrm{ZnAc}$ immediately after centrifugation and analysed by the methylene blue technıque of Cline (1969). Some sulfide may have been lost by evaporation and oxidation during centrifugation, but due to the very low level of free 
sulfide in these sediments (no or only weak sulfide smell) this loss is assumed to be insignificant for the overall sulfur budget.

Sulfate reduction and inorganic sulfur pools. Sulfate reduction was measured by the core injection technique (Jørgensen 1978). A volume of $4 \mu \mathrm{l}$ carrier-free ${ }^{35} \mathrm{~S}$ $\mathrm{SO}_{4}^{2-}(120 \mathrm{kBq})$ was injected at $1 \mathrm{~cm}$ intervals to a depth of $10 \mathrm{~cm}$ in 3 undisturbed cores from each station. The cores were incubated without overlying water for $20 \mathrm{~h}$ in darkness at $29^{\circ} \mathrm{C}$ before being cut into segments and transferred to $20 \% \mathrm{ZnAc}$ (vol 1:1) and frozen to terminate incubation and fix sulfides. The fraction of ${ }^{35} \mathrm{~S}_{-} \mathrm{SO}_{4}{ }^{2-}$ reduced during the incubation was determined as the sum of ${ }^{35} \mathrm{~S}$ in the acid volatile (AVS, defined as FeS and free sulfide) and the chromium reducible (CRS, defined as $\mathrm{FeS}_{2}$ and $\mathrm{S}^{\circ}$ ) sulfide pools.

The 2-step distillation procedure of Fossing \& Jørgensen (1989) was used to recover AVS and CRS from the sediment. Briefly, sediment samples were mixed and washed 5 times to remove ${ }^{35} \mathrm{~S}-\mathrm{SO}_{4}^{2-}$. About $1 \mathrm{~g}$ of each sediment pellet was transferred to a reaction flask with $10 \mathrm{ml} 50 \%$ ethanol. After degassing and acidification ( $8 \mathrm{ml} 12 \mathrm{M} \mathrm{HCl}$ ), AVS was liberated as $\mathrm{H}_{2} \mathrm{~S}$ at room temperature under continuous stirring for 40 min using $\mathrm{N}_{2}$ as a carrier gas and trapped as $\mathrm{ZnS}$ in $10 \mathrm{ml} 5 \% \mathrm{ZnAc}$. CRS was determined in the sediment slurry remaining from the AVS distillation. A new ZnAc trap was inserted and $16 \mathrm{ml} \mathrm{Cr}^{2+}$ in $0.5 \mathrm{M} \mathrm{HCl}$ was added before distillation was resumed by $45 \mathrm{~min}$ of boiling. All traps were later analysed for sulfide to recover the total reduced sulfur pools. Radioactivity of ${ }^{35} \mathrm{~S}$ in the traps were determined on subsamples using a Packard 2200 CA TRI-CARB Scintillation Analyzer.

Elemental sulfur was separated by the $\mathrm{CS}_{2}$ extraction method of Howarth \& Jørgensen (1984). Subsamples of 2 to $3 \mathrm{~g}$ sediment were extracted with $5 \mathrm{ml} \mathrm{CS_{2 }}$ in glassstoppered test tubes for $12 \mathrm{~h}$ on a shaker at room temperature. After centrifugation the supernatant was analyzed spectrophotometrically for $\mathrm{S}^{\circ}$ (Troelsen \& Jørgensen 1982) and counted for ${ }^{35} \mathrm{~S}$ radioactivity.

FeS was determined as the distilled AVS by subtraction of free sulfide and $\mathrm{FeS}_{2}$ as the distilled CRS after subtraction of the measured $\mathrm{S}^{\circ}$ content.

Solid phase iron. Total Fe content in the particulate phase was determined on $100^{\circ} \mathrm{C}$ dried and ground sediment samples. About $0.1 \mathrm{~g}$ of dry sediment was digested with $5 \mathrm{ml}$ of hot $10 \mathrm{M} \mathrm{HNO}_{3}$ for $20 \mathrm{~h}$. After digestion the solution was evaporated to near dryness. The residue was then dissolved in hot concentrated $\mathrm{HCl}$, diluted with distilled water to give about $1 \mathrm{M} \mathrm{HCl}$ and centrifuged at $3000 \mathrm{rpm}$ for $10 \mathrm{~min}$. The resulting digest was analyzed for Fe by atomic absorption spectrometry (Perkin-Elmer 2380 AAS).

Redox, pH and alkalinity. Vertical redox profiles were determined with a Pt-electrode inserted into the sediment in steps of $1 \mathrm{~cm}$ down to $10 \mathrm{~cm}$. The Eh signal was allowed to stabilize for $3 \mathrm{~min}$ at each depth before the reading was noted. Six replicate profiles were measured at each station.

Profiles of $\mathrm{pH}$ in the sediment were measured in intervals of $2 \mathrm{~mm}(0$ to $1 \mathrm{~cm})$ or $1 \mathrm{~cm}(1$ to $10 \mathrm{~cm})$. After core sectioning, the segments were immediately transferred to $5 \mathrm{ml}$ scintillation vials and a Knick U 456-KN $2 \mathrm{pH}$ electrode with a $5 \mathrm{~mm}$ wide tip was inserted directly into the sediment. The $\mathrm{pH}$ reading was noted after 5 to 10 min of stabilization. Four profiles were determined at each of the stations.

Pore water alkalinity was determined in 3 replicates at each station by titration with $0.01 \mathrm{M} \mathrm{HCl}$. Unfortunately, all alkalinity samples had to be diluted with distilled water before titration due to the small amounts of pore water available. However, subsequent dilution tests showed no significant errors due to this method.

On one occasion, $\mathrm{pH}$ and alkalinity changes in the tidal water passing the creek adjacent to Stn 2 was followed during one tidal cycle. Water samples from the creek were taken by syringe at $1 \mathrm{~h}$ intervals from 8.00 to $19.00 \mathrm{~h}$ and filtered through GF/C filter in the field. The samples were analysed the same day.

Oxygen and carbon dioxide exchange. Total metabolic rate of the sediment was determined as oxygen uptake and carbon dioxide production on cores kept in darkness. Four cores $(15 \mathrm{~cm}$ sediment and $10 \mathrm{~cm}$ water column) from each of the stations were supplied with an overlying water phase of fresh sea water immediately after arrival to the laboratory. The cores were equilibrated in darkness with continuous aeration for about $20 \mathrm{~h}$ before initiation of flux measurements. The water phase was replaced twice during this dark acclimation period to avoid accumulation of metabolites. Temperature was $29^{\circ} \mathrm{C}$ during both acclimation and incubation. During incubations all cores were equipped with stirrer motors which maintained a continuous water circulation at a rate less than the resuspension limit. Flux rates were determined from the concentration difference between initial and final samples during incubation periods of 2 to $4 \mathrm{~h}$. Oxygen was analysed by the standard Winkler technique (Parsons et al. 1984). Total carbon dioxide $\left(\mathrm{TCO}_{2}\right)$ was quantified by potentiometric Gran titration (Talling 1973).

\section{RESULTS}

\section{Sediment characteristics}

Stn 1 was heavily bioturbated by burrowing ocypodid and grapsid crabs (1550 burrow openings $\mathrm{m}^{-2}$ ). Very slow tidal currents at this station allowed for the deposition of a thick silt layer. The sediment was com- 
posed of grey-brown silt and clay deposits down to a depth of 10 to $12 \mathrm{~cm}$, followed by a narrow $(5$ to $7 \mathrm{~cm}$ ) sandy zone which overlay a compact zone of unknown depth dominated by coarse gravel and pebbles. Organic contents were constant with depth in the upper $10 \mathrm{~cm}$ : 4 to $6 \%$ LOI; 700 to $900 \mu \mathrm{mol} \mathrm{C} \mathrm{g} \mathrm{dw}^{-1}$;

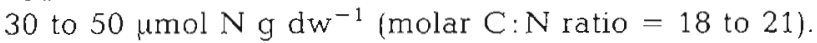
Although the infrequent inundations (10 to 15 tides per month) gave the impression of a rather dry sediment surface, water contents and porosity $(0.5$ to 0.6$)$ were similar to those found at the other 2 stations. The numerous burrows, which usually reached to 15 to 20 $\mathrm{cm}$ depth, were responsible for a 5 to $10 \mathrm{~cm}$ thick, continuous light brown oxidized upper zone. Deeper down, the oxidized zone was restricted to a $5 \mathrm{~mm}$ radial layer around burrows. The bulk reduced sediment was never black and sulfidic.

Stn 2 was less affected by burrowing fauna. The major infaunal species were sipunculid worms $(500$ $\left.\mathrm{m}^{-2}\right)$ and grapsid crabs $\left(10 \mathrm{~m}^{-2}\right)$. The sediment consisted of a 4 to $5 \mathrm{~cm}$ thick grey-brown silt-zone overlying a grey-black peat-like root zone down to at least $15 \mathrm{~cm}$ depth. This 2-layered structure is probably the combined result of silt sedimentation at the surface during high tide and continuous root growth at 4 to $5 \mathrm{~cm}$ depth by Rhizophora apiculata. Organic content in the silt zone was 5 to $6 \%$ LOI; 900 to $1200 \mu \mathrm{mol} \mathrm{C} \mathrm{g}$ $\mathrm{dw}^{-1} ; 40$ to $50 \mu \mathrm{mol} \mathrm{N} \mathrm{g} \mathrm{dw}{ }^{-1}(\mathrm{C}: \mathrm{N}=22$ to 27$)$, whereas the richer root zone gave values of 7 to $8 ; 1400$ to $1500 ; 50$ to 60 , respectively ( $\mathrm{C}: \mathrm{N}=25$ to 27 ). The silt zone, which had an upper 0.5 to $1 \mathrm{~cm}$ thick light brown oxidized zone, was never black and sulfidic. The root zone, on the other hand, had scattered spots of black sulfidic sediment, particularly around dead roots.

The Stn 3 sediment appeared more sandy than at the other 2 stations. Wave action and strong tidal currents probably resuspend and remove the fine particulate fraction at the surface frequently. The dominating burrowing benthic fauna, ocypodid crabs $\left(10 \mathrm{~m}^{-2}\right)$, mudskippers (Gobioidae) $\left(5 \mathrm{~m}^{-2}\right)$ and small polychaetes $\left(200 \mathrm{~m}^{-2}\right)$, was outnumbered by epibenthic cerithiid snails $\left(520 \mathrm{~m}^{-2}\right)$. The sediment consisted of silty sand down to a depth of 9 to $12 \mathrm{~cm}$ followed by a zone of coarse coral sand. Organic content in the upper $2 \mathrm{~cm}$ was low with values around $4 \%$ LOI; $500 \mu \mathrm{mol} \mathrm{C} \mathrm{g}$ $\mathrm{dw}^{-1} ; 18$ umol $\mathrm{N} \mathrm{g} \mathrm{dw}^{-1}(\mathrm{C}: \mathrm{N}=28)$, whereas values of 5 to $6 ; 900$ to $1300 ; 30$ to 40 , respectively ( $C: N=30$ to 35) were obtained deeper down. The presence of coral sand was evident as high particulate inorganic carbon (PIC) values in the deeper layers. The 8 to $10 \mathrm{~cm}$ depth interval exhibited a PIC content of 2330 umol $\mathrm{C} \mathrm{g} \mathrm{dw^{-1 }}$ which was about twice the measured POC content. At the other stations PIC was generally below $10 \mu \mathrm{mol} \mathrm{C} \mathrm{g} \mathrm{dw}^{-1}$. The upper zone of the Stn 3 sediment had a 0.5 to $1 \mathrm{~cm}$ oxidized surface layer overlying a grey-black reduced zone. The sediment was non-sulfidic in the depth interval examined.

\section{Sediment metabolism}

Oxygen uptake and carbon dioxide production

Surface $\mathrm{O}_{2}$ uptake $\left(\mathrm{J}_{\mathrm{O}_{2}}\right)$ and $\mathrm{CO}_{2}$ production $\left(\mathrm{J}_{\mathrm{CO}_{2}}\right)$ were highest at Stn 1, attaining values 37 and $23 \%$ higher than at Stn 2 where the rates were lowest (Table 1). The differences between the 3 stations appeared to be significant only for $\mathrm{J}_{\mathrm{O}_{2}}$. The community respiratory quotient (CRQ) was close to 1.5 for all stations.

Table 1. Rates of $\mathrm{O}_{2}$ uptake $\left(\mathrm{J}_{\mathrm{O}_{2}}\right) ; \mathrm{CO}_{2}$ production $\left(\mathrm{J}_{\mathrm{CO}_{2}}\right)$; and depth-integrated $(0$ to $10 \mathrm{~cm}$ ) SO 4 reduction ( $\Sigma \mathrm{SRR}$ ) for the 3 stations in the Ao Nam Bor mangrove. Values ( $\pm \mathrm{SD}$ for $\mathrm{J}_{\mathrm{O}_{2}}$ and $\mathrm{J}_{\mathrm{CO}_{2}}$ ) are in mmol $\mathrm{m}^{-2} \mathrm{~d}^{-1}$ The community respiration quotient $\left(\mathrm{CRQ}=\mathrm{J}_{\mathrm{CO}_{2}} / \mathrm{J}_{\mathrm{O}_{2}}\right)$ is presented. Estimated $\mathrm{CO}_{2}$ production from $\mathrm{SO}_{4}^{2-}$ reduction $(2 \times \Sigma \mathrm{SRR})$ is given as percentage of $\mathrm{J}_{\mathrm{CO}_{2}}\left(\%\right.$ of $\left.\mathrm{J}_{\mathrm{CO}_{2}}\right)$

\begin{tabular}{|cccccc|}
\hline $\mathrm{Stn}$ & \multicolumn{1}{c}{$\mathrm{J}_{\mathrm{O}_{2}}$} & $\mathrm{~J}_{\mathrm{CO}_{2}}$ & $\mathrm{CRQ}$ & $\Sigma \mathrm{SRR}$ & $\%$ of $\mathrm{J}_{\mathrm{CO}_{2}}$ \\
\hline 1 & $61.1 \pm 18.8$ & $86.1 \pm 26.7$ & 1.41 & 27.8 & 64.6 \\
2 & $44.7 \pm 3.1$ & $69.9 \pm 16.5$ & 1.56 & 49.7 & 142.2 \\
3 & $50.0 \pm 2.4$ & $77.2 \pm 5.4$ & 1.54 & 43.4 & 112.4 \\
\hline
\end{tabular}

\section{Sulfate reduction}

Although sulfate reduction generally increased with depth at all stations, the depth profiles of sulfate reduction rate (SRR) reflected the sediment composition at each station (Fig. 2). Thus, an inverse relationship was evident between SRR and Eh (Fig. 3). SRR at Stn 1 was lowest in the bioturbated and relatively oxidized upper $8 \mathrm{~cm}$. Below this zone the rate almost doubled to a value of ca $600 \mathrm{nmol} \mathrm{S} \mathrm{cm}{ }^{-3} \mathrm{~d}^{-1}$ (Fig. 2). At Stn 2 the depressed SRR at 4 to $6 \mathrm{~cm}$ depth coincided with the zone of active roots. The steep increase in SRR to ca 800 $\mathrm{nmol} \mathrm{S} \mathrm{cm} \mathrm{cm}^{-3} \mathrm{~d}^{-1}$ below the active root zone was associated with a significant drop in Eh. In the reduced coral sand zone $(8$ to $10 \mathrm{~cm}$ ) of Stn 3, however, SRR $(250 \mathrm{nmol}$ $\mathrm{S} \mathrm{cm}{ }^{-3} \mathrm{~d}^{-1}$ ) was only $1 / 3$ of the peak rate just above ( 6 to $8 \mathrm{~cm}$ ). The integrated SRR in the depth interval from 0 to $10 \mathrm{~cm}$ was almost similar at Stns 2 and 3 with a rate twice as high as that found at Stn 1 (Table 1).

$\mathrm{FeS}_{2}$ was generally the most important end-product during the sulfate reduction assays. However, within and between the 3 stations some variation occurred. At Stn 1 , 53 to $80 \%$ of the label was recovered in the $\mathrm{FeS}_{2}$ pool with the highest values found at intermediate depths. The remainder was almost entirely recovered as FeS since $\mathrm{S}^{\circ}$ only accounted for 0.2 to $1.4 \%$. The recovery of label 


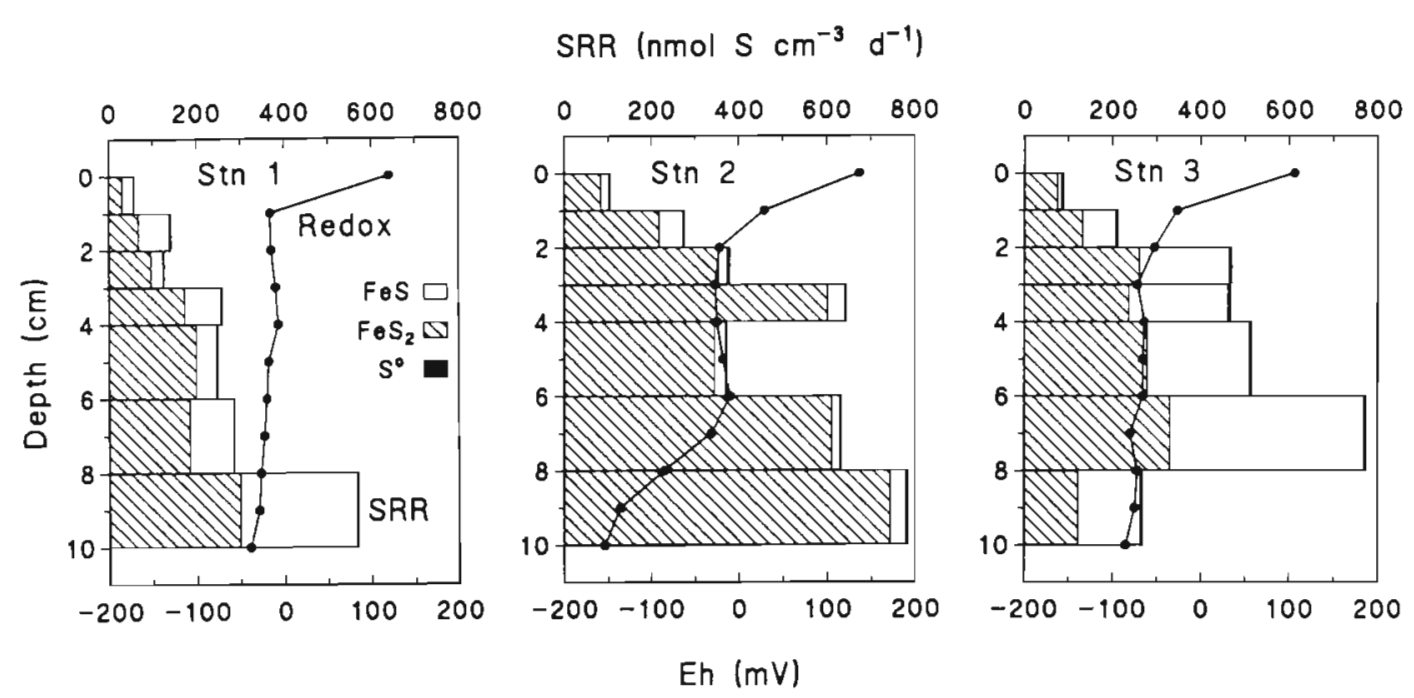

Fig. 2. Depth distribution of sulfate reduction rate and redox at the 3 stations. The sulfate reduction bars indicate the relative recoveries of ${ }^{35} \mathrm{~S}$ in the 3 examined pools of reduced inorganic sulfur

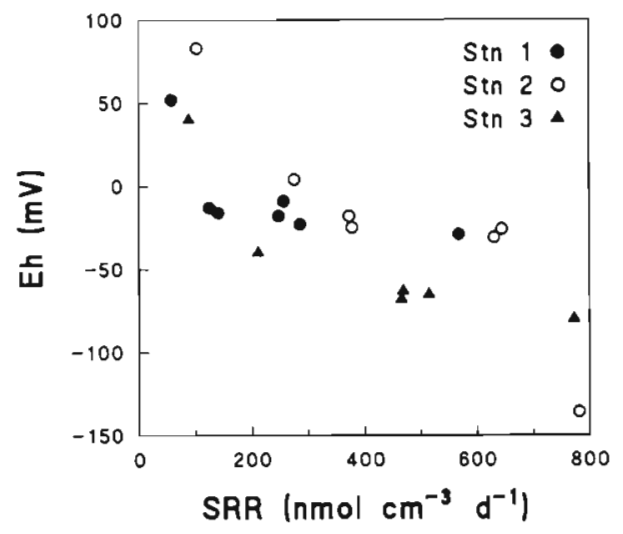

Fig. 3. Relationship between redox (Eh) and sulfate reduction rates (SRR). Data points represent all 3 sampling stations as $\mathrm{FeS}_{2}$ at Stn 2 increased with depth from ca $80 \%$ at the surface to $95 \%$ at $10 \mathrm{~cm}$ depth with a corresponding decrease of labelled FeS and $\mathrm{S}^{\circ}$ (18 to $4.5 \%$ and 2 to $0.4 \%$, respectively). The label recovered as FeS at Stn 3 increased dramatically with depth, from 15 to $57 \%$. The remaining label was found in the $\mathrm{FeS}_{2}$ pool, except for the upper $2 \mathrm{~cm}$ where $\mathrm{S}^{\circ}$ accounted for 3 to $5 \%$.

\section{Pore water and sediment chemistry \\ Inorganic sulfur pools}

The pool of reduced inorganic sulfur almost doubled with depth from the surface to $10 \mathrm{~cm}$ depth in all 3 mangrove sediments (from about 50 to $115 \mu \mathrm{mol} \mathrm{cm} \mathrm{cm}^{-3}$ at Stns 1 and 3, and from about 100 to $190 \mu \mathrm{mol} \mathrm{cm}^{-3}$ at

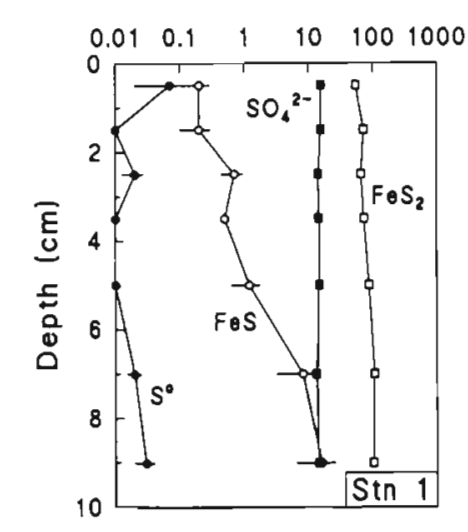

Sulfur pools ( $\mu \mathrm{mol} S \mathrm{~cm}^{-3}$ )
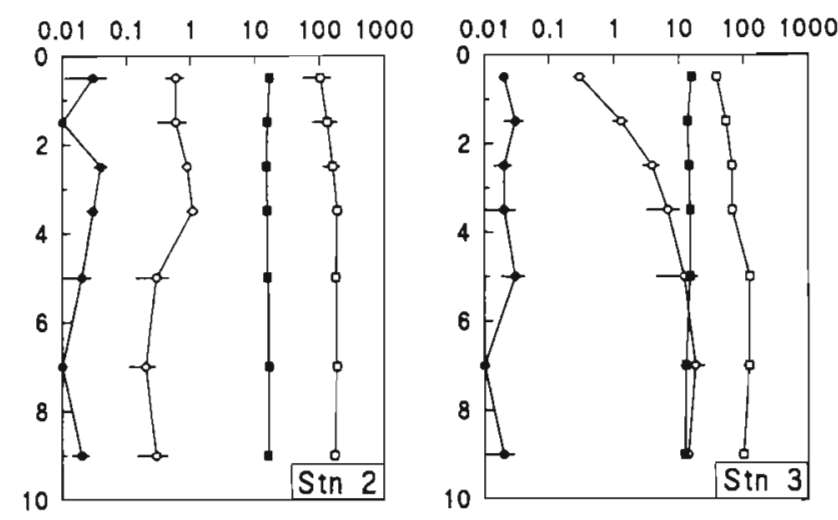

Fig. 4. Depth distribution of inorganic sulfur pools in the 3 examined sediments. Error bars indicate \pm SE. Note logarithmic concentration scale 
Stn 2; Fig. 4). $\mathrm{FeS}_{2}$ was the most important reduced inorganic sulfur species. About 86 to almost $100 \%$ of the total pool was recovered as $\mathrm{FeS}_{2}$, whereas FeS only exceeded $1 \%$ in the deeper layers of Stns 1 and 3 reaching $13 \%$ at $10 \mathrm{~cm}$ depth. At Stn 2 the $\mathrm{FeS}$ content decreased from $0.6 \%$ to $0.1 \%$ with depth from the siltzone to the root-zone. Elemental sulfur generally accounted for less than $0.1 \%$ of the total pool. Free sulfide was only measurable at $\operatorname{Stn} 2$ and in very low concentrations, 5 to $10 \mathrm{nmol} \mathrm{cm}^{-3}$. Accordingly, no sulfide smell was noticed at any time from freshly collected sediment cores from Stns 1 and 3 .

Only limited $\mathrm{SO}_{4}{ }^{2-}$ depletion was evident at any of the 3 stations (Fig. 4). The $\mathrm{SO}_{4}^{2-}$ concentration decreased from between 16 and $17 \mu \mathrm{mol} \mathrm{cm}^{-3}$ in the uppermost $\mathrm{cm}$ to between 13 and $16 \mu \mathrm{mol} \mathrm{cm} \mathrm{cm}^{-3}$ at $10 \mathrm{~cm}$ depth.

\section{Iron}

The $\mathrm{HNO}_{3}$ extractable total iron $(\mathrm{tFe}$ ) content in the 3 mangrove sediments ranged from 350 to $660 \mu \mathrm{mol} \mathrm{cm} \mathrm{cm}^{-3}$ (Fig. 5). The tFe content was lowest in the 2 to $10 \mathrm{~cm}$ depth interval of Stn 1 and the upper $4 \mathrm{~cm}$ of Stn 2. In the root zone of Stn $2(4$ to $10 \mathrm{~cm}$ ) and in the upper $6 \mathrm{~cm}$ at $\mathrm{Stn} 3, \mathrm{tFe}$ content appeared about $50 \%$ higher. In the coral sand zone of Stn 3 the tFe content was about $20 \%$ lower than in the zone above.

Pyritization, $P$, is defined here as the fraction of the $\mathrm{HNO}_{3}$ extractable iron pool which was bound in pyrite: $P=\mathrm{Fe}_{\mathrm{py}} / \mathrm{tFe}$, where $\mathrm{Fe}_{\mathrm{py}}$ is the pyrite-bound iron pool. This definition is similar to that of Berner (1970) only if $\mathrm{tFe}=\mathrm{Fe}_{\mathrm{py}}+\mathrm{Fe}_{\mathrm{HCl}}\left(\mathrm{Fe}_{\mathrm{HCl}}\right.$ is iron extracted in boiling 12 $\mathrm{M} \mathrm{HCl}$ for $1 \mathrm{~min}$ ). $P$ increased with depth in the 2 nonrooted sediments (Stns 1 and 3 ) from 5 and $3 \%$ in the uppermost layers to 18 and $16 \%$ at 8 to $10 \mathrm{~cm}$ depth. respectively (Fig. 5). The silt-zone of $\operatorname{Stn} 2$ sediment showed an increase from 12 to $23 \%$, but $P$ declined again in the root-zone attaining constant values around $15 \%$ down to at least $10 \mathrm{~cm}$ depth.

\section{pH and alkalinity}

The 3 sediments showed very different $\mathrm{pH}$ and alkalinity profiles (Fig. 6). In the highly bioturbated Stn 1 a constant $\mathrm{pH}$ around 7 was observed for the entire depth interval examined. Stn 2, on the other hand, appeared rather acidic with $\mathrm{pH}$ decreasing from 7 at the surface to around 6.4 in the 1 to $5 \mathrm{~cm}$ depth interval of the silt zone. In the root zone $\mathrm{pH}$ increased slightly to around 6.7. The mudflat sediment (Stn 3) had a pH profile typical of marine sediments with a distinct minimum at $0.5 \mathrm{~cm}$ depth $(\mathrm{pH}=6.9$ ) followed by a gradual increase to 7.4 at $10 \mathrm{~cm}$ depth.

Alkalinity was generally low in all 3 mangrove sediments (Fig, 6). At Stns 1 and 2 alkalinity decreased from 2.3 and $2.8 \mathrm{meq} .1^{-1}$, respectively, at the surface to 1.3 and 2.0 meq. $1^{-1}$ at 2 to $3 \mathrm{~cm}$ depth. At Stn 1 alkalinity remained constantly low down to a depth of 8 to $10 \mathrm{~cm}$, whereas at $\mathrm{Stn} 2$ there was a gradual increase in the deeper part of the root zone, reaching $3.8 \mathrm{meq}$. $1^{-1}$ at 8 to $10 \mathrm{~cm}$ depth. At Stn 3 alkalinity remained constant around $2.9 \mathrm{meq} . \mathrm{l}^{-1}$ for the depth interval examined. The 3 stations apparently represented an alkalinity gradient with a trend for deeper subsurface minimum towards the more dry inland stations. On one occasion where alkalinity was measured down to $20 \mathrm{~cm}$ depth at Stn 1 (data not shown) a pattern similar to that at Stn 2, but more extended, was observed with a
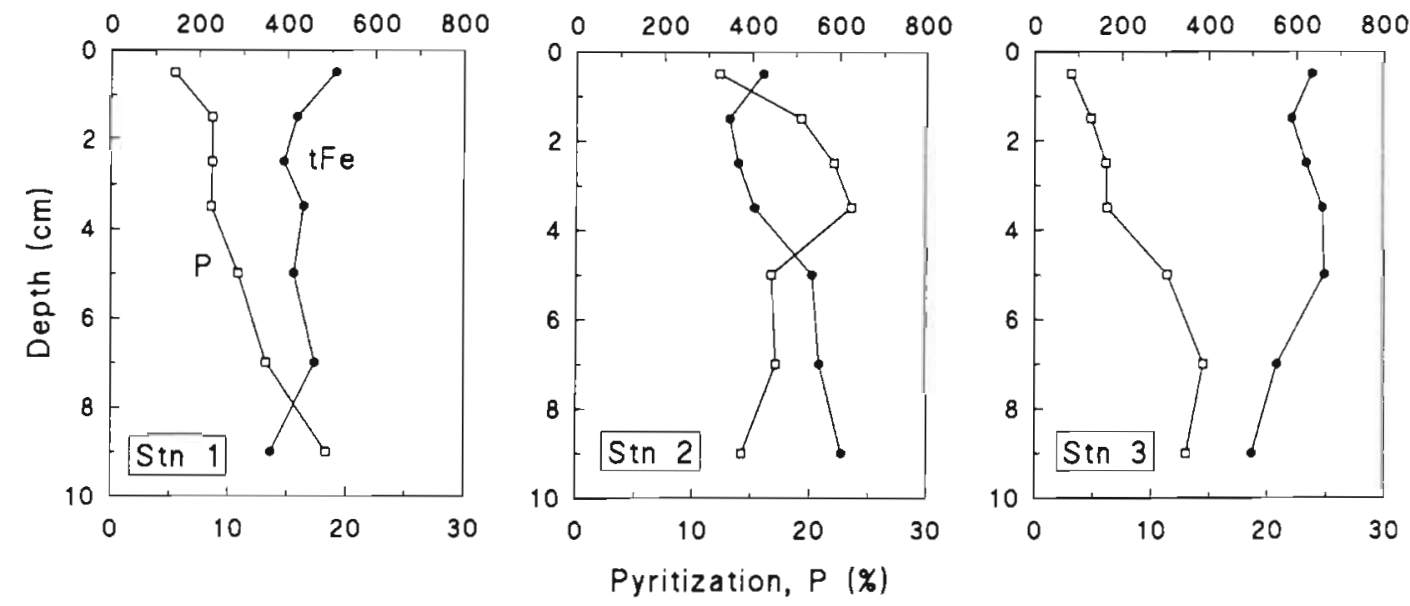

Fig. 5. Depth distribution of $\mathrm{HNO}_{3}^{-}$extractable iron ( $\mathrm{tFe}$ ) and pyritization $(P)$ in the 3 mangrove sediments 


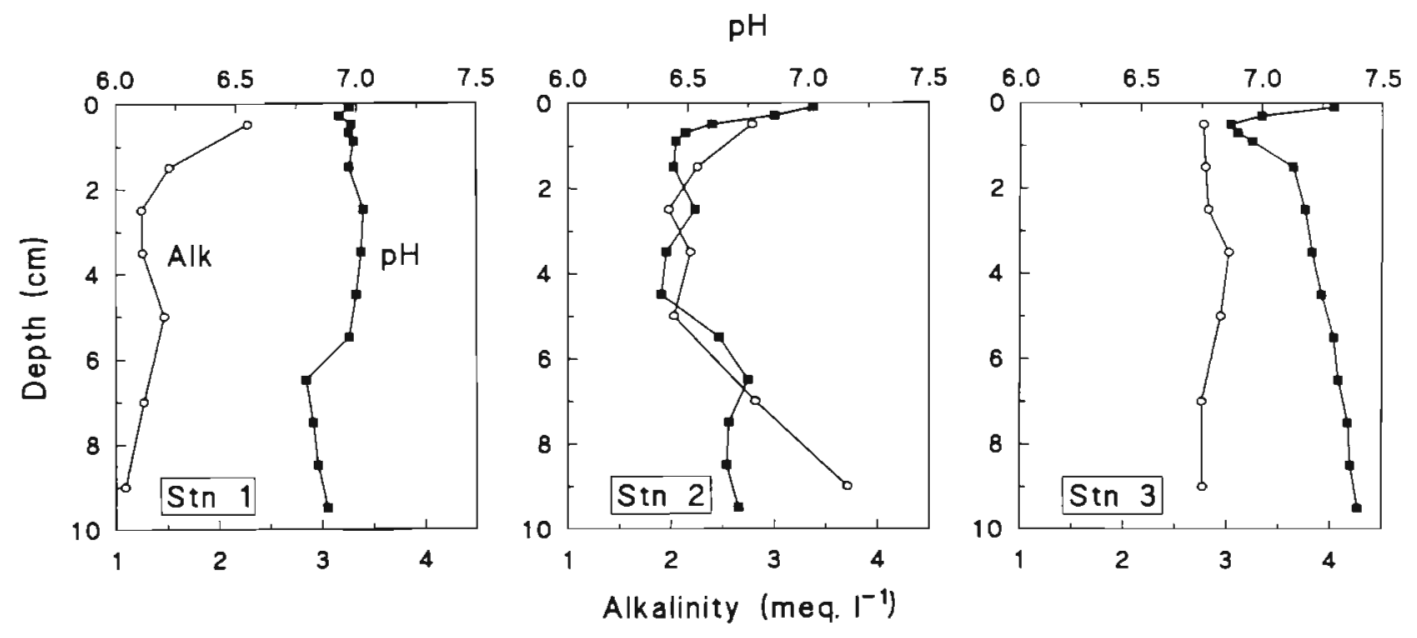

Fig. 6. Depth profiles of bulk sediment $\mathrm{pH}$ and titration alkalinity at the 3 examined stations. Error bars indicate $\pm \mathrm{SE}$

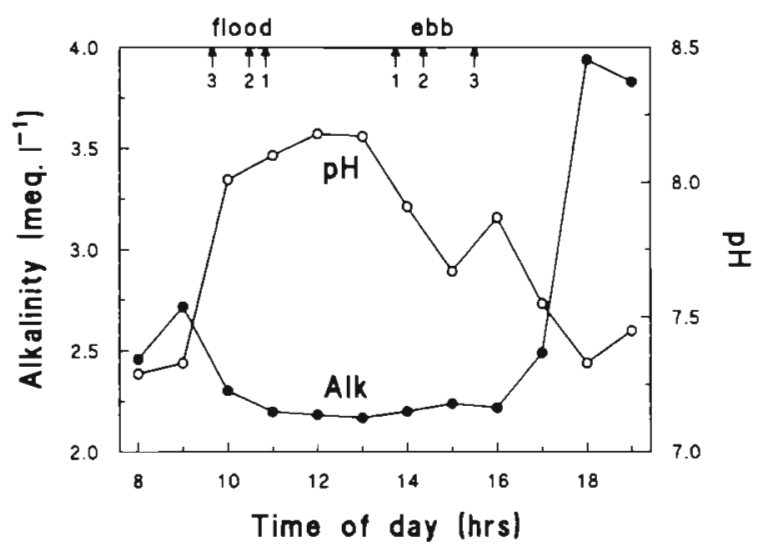

Fig. 7 Temporal pattern of $\mathrm{pH}$ and alkalinity in creek water adjacent to Stn 2 during one tidal cycle. Arrows indicate when Stns 1, 2 and 3, respectively, are inundated during flood and exposed to air during ebb

gradual increase from 1.1 meq. $1^{-1}$ at 8 to $10 \mathrm{~cm}$ to 2.3 meq. $\mathrm{l}^{-1}$ at 18 to $20 \mathrm{~cm}$.

Temporal changes in creek water $\mathrm{pH}$ and alkalinity during one tidal period are shown in Fig. 7. Values typical for oceanic water $(\mathrm{pH} \approx 8.2$ and alkalinity $\approx 2.1$ meq. $1^{-1}$ ) were rapidly attained at high tide. During ebb, however, pH gradually dropped to $\approx 7.3$ whereas alkalinity increased abruptly to $\approx 4$ meq. $\mathrm{l}^{-1}$.

\section{DISCUSSION}

\section{Sulfate reduction and distribution of sulfur pools}

The depth-integrated rates of sulfate reduction in sediments of the tropical mangrove, Ao Nam Bor, (28 to $50 \mathrm{mmol} \mathrm{m} \mathrm{m}^{-2} \mathrm{~d}^{-1}$; Table 1) are within the range found in nearshore subtidal sediments but are low compared to most salt marshes (e.g. Skyring 1987). Sulfate reduction rates at the 3 stations generally appear to be associated with low redox potentials; high rates are found only where Eh is below -40 to $-50 \mathrm{mV}$ (Figs. 2 \& $3)$. This threshold is in accordance with the results of Balzer et al. (1983). The distinct subsurface maximum in sulfate reduction observed around 6 to $10 \mathrm{~cm}$ depth at all stations (Fig. 2) indicates a vertical translocation of metabolizable organic substrates within the sediment (Howarth \& Teal 1979), either due to subsurface root growth or due to downward transport of newly deposited organic matter from the surface by bioturbation. In subtidal coastal sediments, where most of the freshly deposited organic matter remains at or near the surface, a sharp peak of sulfate reduction close to the sediment surface is normally followed by a rapidly decreasing rate with depth and more than $80 \%$ of the total activity is usually concentrated in the upper $10 \mathrm{~cm}$ (Goldhaber et al. 1977, Jørgensen 1982, Berner \& Westrich 1985, Swider \& Mackin 1989). The areal rates presented here for the upper $10 \mathrm{~cm}$ are likely to underestimate the true depth-integrated rates for the entire sediment system since substantial sulfate reduction may occur below $10 \mathrm{~cm}$ depth. Significant rates are expected to occur down to the gravel zone at Stn 1 (ca $17 \mathrm{~cm}$ depth) and even deeper down at Stn 2. At Stn 3, however, the low rates observed at 8 to $10 \mathrm{~cm}$ depth suggest that sulfate reduction is relatively low in the coral sand below. The depth-integrated rates should thus be considered minimum estimates, especially for Stns 1 and 2. It is vital, therefore, that future studies on sulfate reduction in mangrove sediments include deeper layers $(>10 \mathrm{~cm})$ to clarify the exact depth distribution of this important process. 
The very high recovery of reduced ${ }^{35} \mathrm{~S}$-label found as $\mathrm{FeS}_{2}(82$ to $97 \%$ ) in Stn 2 sediment demonstrates the necessity to include the CRS fraction when sulfate reduction is measured in rooted sediments rich in peat. This is a phenomenon frequently observed in tidally dominated Spartina marshes (Howarth \& Giblin 1983, Howarth \& Merkel 1984. Swider \& Mackin 1989). The only available data on sulfate reduction in southeast Asian mangrove swamps is from the study of Blackburn et al. (1987). Unfortunately, their results were only based on the ${ }^{35} \mathrm{~S}$-label trapped in the AVS pool, which probably underestimates the true rates more than 10-fold. However, the depth-integrated (AVS based) sulfate reduction of Blackburn et al. (1987) in the upper $10 \mathrm{~cm}$ of the sediment from a Rhizophora apiculata mangrove (Ao Yon, Phuket Island), $5.4 \mathrm{mmol} \mathrm{m}^{-2} \mathrm{~d}^{-1}$, is close to the AVS based sulfate reduction found at the $R$. apiculata site (Stn 2) in the present study, $3.7 \mathrm{mmol} \mathrm{m} \mathrm{m}^{-2} \mathrm{~d}^{-1}$ The oxidizing activity of roots and relatively low $\mathrm{pH}$ in this type of sediment may favour a rapid formation of $\mathrm{FeS}_{2}$ either through direct precipitation of $\mathrm{Fe}^{2+}$ with polysulfides or via FeS oxidation with $S^{\circ}$ and polysulfides (Berner 1964, Howarth 1979, Giblin \& Howarth 1984, Giblin 1988). The non-rooted and more sandy Stns 1 and 3 , where only 43 to $80 \%$ of the ${ }^{35}$ S-label was found in the CRS fraction, have $\mathrm{pH}$ levels (7.0 to 7.5) similar to subtidal, coastal sediments. In these types of sediment the AVS fraction usually is the most important end-product (Howarth \& Jørgensen 1984, ThodeAndersen \& Jørgensen 1989). In other coastal sediments the net formation of $\mathrm{S}^{\circ}$ during short-term sulfate reduction assays is usually more important than found here (King 1988, Thode-Andersen \& Jørgensen 1989). Due to the potential role of isotopic exchange reactions between $S^{\circ}$ and other reduced sulfur pools and to the fact that AVS is an operationally defined fraction, however, the distribution of sulfate reduction into FeS, $\mathrm{S}^{\circ}$ and $\mathrm{FeS}_{2}$ is only indicative of the tracer distribution and not of the differential formation rates of these compounds (Thode-Andersen \& Jørgensen 1989).

Almost all (86 to $100 \%$ ) reduced sulfur at the 3 stations is found as $\mathrm{FeS}_{2}$ (Fig.4). In most subtidal sediments $\mathrm{FeS}_{2}$ usually accounts for 30 to $50 \%$ of the reduced sulfur pool (Thode-Andersen \& Jørgensen 1989), whereas this compound generally is the major particulate sulfur component ( 50 to $90 \%$ ) in salt marsh sediments (Howarth \& Teal 1979, Luther et al. 1982, Howarth \& Giblin 1983). The $\mathrm{S}^{\circ}$ content close to the detection limit, on the other hand, is low compared to most coastal sediments where this compound usually accounts for 2 to $10 \%$ of the total reduced sulfur pool in the upper $10 \mathrm{~cm}$ (King et al. 1985, Thode-Andersen \& Jørgensen 1989).
The total iron content of these sediments is 2 to 3 times the values previously found in salt marshes (Giblin 1988) and coastal sediments (Sørensen \& Jørgensen 1987, Jørgensen et al, 1990). The long-term $\mathrm{HNO}_{3}$ extraction procedure used here, however, may overestimate the pool of reactive iron by extracting a part of the large pool which is bound in silicate minerals (Canfield 1989). Pyritization, $P$, which is defined slightly different here than in previous studies, was generally low in the mangrove sediments, but close to the values found by others (Berner 1970, Jørgensen et aI. 1990). The high tFe content and low $P$ may indicate that $\mathrm{FeS}$ and $\mathrm{FeS}_{2}$ formation in the present sediments not are limited by the availability of reactive iron. This is substantiated by the general absence of free $\mathrm{HS}^{-}$in the sediment despite the relatively high rates of sulfate reduction. Thus, Canfield (1989) demonstrated that in marine sediments supporting sulfate reduction, the presence or absence of $\mathrm{HS}^{-}$is a sensitive indicator as to the presence of reactive iron oxides. Continued reoxidation of iron sulfide minerals by action of roots, crabs and other physical processes may replenish iron oxides constantly at all depth strata in the sediment. Without this renewal the present mangrove sediments would be considerably more reduced.

The low pyritization observed in the upper 4 to $6 \mathrm{~cm}$ of the sediment at Stns 1 and 3 probably reflects active removal of $\mathrm{FeS}_{2}$ as opposed to the less disturbed $\mathrm{FeS}_{2}$ rich Stn 2. Burrowing activity by the numerous crabs at Stn 1 transports sediment from deeper strata to the surface where $\mathrm{FeS}_{2}$ is oxidized or removed. Gardner et al. (1988) found that fiddler crab burrowing could remove $17.5 \%$ of the $\mathrm{FeS}_{2}$ produced by sulfate reduction each year in a South Carolina (USA) salt marsh. Removal or oxidation of $\mathrm{FeS}_{2}$ in the upper layers of the sediment at Stn 3, on the other hand, is in addition to bioturbation probably coupled with the frequent incidences of sediment resuspension at this shallow: wave-exposed station.

\section{Benthic metabolism}

Rates of benthic metabolism measured as $\mathrm{J}_{\mathrm{O}_{2}}$ and $\mathrm{J}_{\mathrm{CO}_{2}}$ (Table 1) are in the lower range of reported rates from coastal sediments and salt marshes in colder climates (Howarth \& Teal 1979. Hargrave \& Phillips 1981, Howarth \& Hobbie 1982, Howes et al. 1984, King et al. 1985, Mackin \& Swider 1989). In a previous study from the Ao Nam Bor mangrove, however, Kristensen et al. (1988) obtained $\mathrm{J}_{\mathrm{O}_{2}}$ values even lower (ca $50 \%$ ) than those presented here. They acclimated cores in the dark for only about $0.5 \mathrm{~h}$ before starting incubation compared to $20 \mathrm{~h}$ in the present study. A very short dark-acclimation period may have resulted in non- 
steady state oxygen gradients and seriously underestimated $\mathrm{J}_{\mathrm{O}_{2}}$ due to the previous light induced oxygen production by benthic microalgae at the sediment surface (Kristensen unpubl.).

Oxygen respiration and sulfate reduction are generally considered the most important respiration processes in coastal marine sediments (Jørgensen 1983, Howarth 1984, Mackin \& Swider 1989). In the present study, the depth-integrated sulfate reduction converted to $\mathrm{CO}_{2}$ production (SRR $\times 2$ ) is comparable to or slightly higher than the measured $\mathrm{J}_{\mathrm{CO}_{2}}$ across the sedimentwater interface (Table 1). This indicates that sulfate reduction in the 0 to $10 \mathrm{~cm}$ layer may be responsible for 65 to $142 \%$ of the total microbial respiration in these sediments. Since significant microbial activity probably occurs below $10 \mathrm{~cm}$ depth, especially at Stns 1 and 2, the actual $\mathrm{CO}_{2}$ production by sulfate reduction is expected to exceed the measured $\mathrm{J}_{\mathrm{CO}_{2}}$ considerably at these stations. The presence of oxygen 1 to $2 \mathrm{~mm}$ into the sediment surface and walls of crab burrows (Andersen \& Kristensen 1988, Kristensen et al. 1988) indicates that oxygen respiration also contributes significantly to $\mathrm{CO}_{2}$ production. Similar discrepancies between measured $\mathrm{CO}_{2}$ flux and $\mathrm{CO}_{2}$ production estimated from sulfate reduction have previously been reported (Howarth \& Giblin 1983, Howarth \& Merkel 1984, Howes et al. 1984, King et al. 1985, Mackin \& Swider 1989). The mechanisms responsible for an apparent $\mathrm{CO}_{2}$ deficit in mangrove sediments may include: (1) $\mathrm{CO}_{2}$ assimilation by Rhizophora apiculata roots (Stn 2) and/or sulfide oxidizing chemoautotrophs (Stns 1 and 2); (2) movements of $\mathrm{CO}_{2}$-rich pore water during low tide by evapotranspiration and seepage into tidal creeks (Stns 1 and 2); (3) wave-induced advective efflux during high tide (Stn 3); and (4) excessive gas exchange during air exposure (Stns 1, 2 and 3).

The effect of Rhizophora apiculata roots on sediment chemistry at Stn 2 is clearly evident from the redox, $\mathrm{pH}$ and alkalinity profiles (Figs. 2 \& 6). The redox depth pattern is closely related to the distribution of living and dead $R$. apiculata roots. The oxidizing activity of living roots is evident as a secondary rise in Eh $(-10$ $\mathrm{mV}$ ) and a depression of sulfate reduction in the 4 to $6 \mathrm{~cm}$ depth interval. Such elevated $E \mathrm{E}$ in active root zones has previously been reported for salt marshes (Howes et al. 1981) and mangrove swamps (Boto \& Wellington 1984). Andersen \& Kristensen (1988) actually observed a narrow oxic zone around roots of the mangrove tree Avicennia marina. The low alkalinity in the 2 to $6 \mathrm{~cm}$ depth interval suggests significant uptake and fixation of $\mathrm{CO}_{2}$ by the roots. Howarth \& Merkel (1984) argued that $\mathrm{CO}_{2}$ assimilation by marsh grasses could obscure measurements of $\mathrm{CO}_{2}$ across the sediment-water interface. The low $\mathrm{pH}$ (6.5) coinciding with the alkalinity minimum in Stn 2 sediment furthermore indicates that sulfide oxidizing chemoautotrophs are present around roots. Assimilation of $\mathrm{CO}_{2}$ by sulfide oxidizers, however, is probably of limited quantitative importance here due to a low growth yield of these bacteria (Howarth 1984). It is also unlikely that chemoautotrophic $\mathrm{CO}_{2}$ fixation in the oxidized wall of the numerous crab burrows at $\operatorname{Stn} 1$ is responsible for the very low alkalinity while bulk sediment $\mathrm{pH}$ remains constant around 7. Salinity (not shown) and sulfate profiles at this station indicate that no freshwater intrusion occurs from land. Bulk sediment $\mathrm{pH}$ measurements, however, do not disclose the presence of acid microzones (e.g. burrow walls) of rapid sulfide oxidation and thereby extensive $\mathrm{CO}_{2}$ liberation. Any evolved $\mathrm{CO}_{2}$ gas may escape easily from the sediment by diffusion into the numerous burrows.

Movement of pore water at Stns 1 and 2 by evapotranspiration and seepage into the tidal creek may result in significant loss of solutes. Such pore water drainage has previously been found to be important for the sediment chemistry in many salt marshes (Howarth \& Teal 1979, Gardner et al. 1988). Although no direct evidence of evapotranspiration was found in the present study, seepage of water at low tide was clearly visible along the creek banks, especially from crevices and infaunal burrows. Samples of the water seeping from these burrows showed high concentrations of both alkalinity (ca 4.5 meq. $\mathrm{I}^{-1}$ ) and free sulfide (ca $50 \mu \mathrm{M}$ ), which confirms the deep origin of this drained pore water. Water seepage clearly affects the water chemistry in the tidal creek; low tide alkalinity in the creek water is almost doubled (ca 4 meq. $\mathrm{l}^{-1}$ ) and $\mathrm{pH}$ is reduced by 1 unit compared to the incoming seawater at high tide (Fig. 7). Accordingly, the advective transport of pore water may be responsible for a considerable loss of metabolically produced $\mathrm{CO}_{2}$ from the sediment column. No seepage occurs at $\operatorname{Stn} 3$ but the waveinduced resuspension of surface sediment may periodically remove significant amounts of pore water solutes, such as $\mathrm{CO}_{2}$, from the upper centimetres of the sediment.

The above mentioned mechanisms may contribute to the discrepancies between measured fluxes and $\mathrm{CO}_{2}$ production estimated from sulfate reduction rates. The $\mathrm{CO}_{2}$ deficit is apparently most serious at Stn 2 , where the potential for $\mathrm{CO}_{2}$ removal by processes other than upward diffusive flux is largest. The incubation technique used in this study has drawbacks which may affect the measured fluxes. Laboratory core incubations may suppress the influence of roots, pore water drainage, and resuspension on fluxes. However, this is usually considered insignificant during short-term measurements when compared to in situ results (Howes et al. 1984). Incubation of tidal sediments with an overlying water phase alone may not be representative for 
the gaseous exchange that occurs during air exposure at low tide. Thus, oxygen fluxes are found to be underestimated from 2 to 10 times when incubations are performed with water above the sediment as compared to gas phase measurements (Dye 1983, Howes et al. 1984, Kristensen unpubl.). This may very well be important in the present study since the sediment is exposed to air for up to $20 \mathrm{~h}$ per day.

Acknowledgements. We are grateful to the staff of PMBC for hospitality and invaluable assistance during this study. We thank $G$. $M$. King and $M$. $H$. Jensen for reviewing the manuscript, and H.Brandt for technical assistance. This work was supported by grant No. 89-0307/60 from the Carlsberg Foundation.

\section{LITERATURE CITED}

Alongi, D. M. (1989). The role of soft-bottom benthic communities in tropical mangrove and coral reef ecosystems. Rev. Aquat. Sci. 1: 243-280

Andersen, F. Ø.. Kristensen, E. (1988). Oxygen microgradients in the rhizophere of the mangrove Avicennia marina. Mar. Ecol. Prog. Ser 44: 201-204

Balzer, W., Grasshoff, K., Dieckmann, P., Haardt, H., Petersohn, U. (1983). Redox-turnover at the sediment/water interface studied in a large bell jar system. Oceanol. Acta 6: $337-344$

Benner, R., Peele, E. R., Hodson, R. E. (1986). Microbial utilization of dissolved organic matter from leaves of the red mangrove Rhizophora mangle, in the Fresh Creek Estuary, Bahamas. Estuar. coast. Shelf Sci. 23: 607-619

Berner, R. A. (1964). An idealized model of dissolved sulphate distribution in recent sediments. Geochim. Cosmochim. Acta 28: 1497-1503

Berner, R. A. (1970). Sedimentary pyrite formation. Am. J. Sci 268: $1-23$

Berner, R. A., Westrich, J. T (1985). Bioturbation and the early diagenesis of carbon and sulfur. Am. J. Sci. 285: 193-206

Blackburn, I H., Christensen, D., Fanger, A. M., Henriksen, K., Iizumi, H., Iversen, N., Limpsaichol, P. (1987). Mineralization processes in mangrove and seagrass sediments. In: Hylleberg, J. (ed.) Ao Yon - a mangrove in the Andaman Sea. Institute of Ecology and Genetics, University of Aarhus, Aarhus, p. 22-32

Boonruang, P. (1978). The degradation rates of mangrove leaves of Rhizophora apiculata (Bl.) and Avicennia marina (Forsk.) Vierh. at Phuket Island, Thailand. Phuket mar Biol Ctr Res. Bull. 26: 1-6

Boto, K. G., Wellington, J. T (1984). Soil characteristics and nutrient status in a northern Australian mangrove forest. Estuaries 7: 61-69

Boto, K. G., Alongi, D. M., Nott, A. L. J. (1989). Dissolved organic carbon - bacteria interactions at sediment-water interface in a tropical mangrove system. Mar Ecol. Prog. Ser. 51: 243-251

Canfield, D. E. (1989). Reactive iron in marine sediments. Geochim Cosmochim. Acta 53: 619-632

Cline, J. D. (1969). Spectrophotometric determination of hydrogen sulfide in natural waters. Limnol. Oceanogr 14: 454-4.58

Cundell, A. M., Brown, M. S., Stanford, R., Mitchell, R. (1979). Microbial degradation of Rhizophora mangle leaves immersed in the sea. Estuar. coast mar. Sci 9: 281-286
Dye, A. H. (1983). Oxygen consumption by sediments in a Southern African mangrove swamp. Estuar coast. Shelf Sci. 17: 473-478

Fossing, H., Jørgensen, B. B. (1989). Measurement of bacterial sulfate reduction in sediments: evaluation of a single-step chromium reduction method. Biogeochemistry 8: 205--222

Frith, D. W., Tantansiriwong, R., Bhatia, O. (1976). Zonation and abundance of macrofauna on a mangrove shore, Phuket Island. Phuket mar. Biol. Ctr Res. Bull. 10: 1-37

Gardner, L. R., Wolaver, I G., Mitchell, M. (1988). Spatial variations in the sulfur chemistry of salt marsh sediments at North Inlet, South Carolina. J. mar. Res. 46: 815-836

Giblin, A. E. (1988). Pyrite formation in marshes during early diagenesis. Geomicrobiol. J. 6: 77-97

Giblin, A. E., Howarth, R. W. (1984). Porewater evidence for a dynamic sedimentary iron cycle in salt marshes. Limnol. Oceanogr. 29: 47-63

Goldhaber, M. B., Aller, R. C., Cochran, J. K., Rosenfeld, J. K., Martens, C. S., Berner, R. A. (1977). Sulfate reduction, diffusion, and bioturbation in Long Island Sound sediments: Report of the FOAM group. Am. J. Sci. 277: 193-237

Gonzales-Farias, F., Mee, L. D. (1988). Effect of mangrove humic-like substances on biodegradation rate of detritus. J. exp. mar Biol. Ecol. 119: 1-13

Hargrave, B. T., Phillips, G. A. (1981). Annual in situ carbon dioxide and oxygen flux across a subtidal marine sediment. Estuar coast. Shelf Sci 12: 725-737

Howarth, R. W. (1979). Pyrite: its rapid formation in a salt marsh and its importance in ecosystem metabolism. Science 203: 49-51

Howarth, R. W. (1984). The ecological significance of sulfur in the energy dynamics of salt marsh and coastal marine sediments. Biogeochemistry 1: 5-27

Howarth, R. W. Giblin, A. (1983). Sulfate reduction in the salt marshes at Sapelo Island, Georgia. Limnol. Oceanogr. 28 $70-82$

Howarth, R. W., Hobbie, J. E. (1982). The regulation of decomposition and heterotrophic microbial activity in salt marsh soils: a review. In: Kennedy, V. S. (ed.) Estuarine comparisons. Academic Press, New York, p. 183-207

Howarth, R. W., Jorgensen, B. B. (1984). Formation of ${ }^{35} \mathrm{~S}$ labelled elemental sulfur and pyrite in coastal marine sediments (Limfjorden and Kysing Fjord, Denmark) during short-term ${ }^{35} \mathrm{SO}_{4}^{2-}$ reduction measurements. Geochim. Cosmochim. Acta 48: 1807-1818

Howarth, R. W. Merkel, S. (1984). Pyrite formation and the measurement of sulfate reduction in salt marsh sediments. Limnol. Oceanogr, 29: 598-608

Howarth, R. W., Teal, J. M. (1979). Sulfate reduction in a New England salt marsh. Limnol. Oceanogr. 24: 999-1013

Howes, B. L., Dacey, J. W. H., King, G. M. (1984). Carbon flow through oxygen and sulfate reduction pathways in salt marsh sediments. Limnol. Oceanogr. 29: 1037-1051

Howes, B. L., Howarth, R. W., Teal, J. M., Valiela, I. (1981) Oxidation-reduction potentials in a salt marsh: spatial patterns and interactions with primary production. Limnol. Oceanogr. 26: 350-360

Jorgensen, B. B. (1978). A comparison of methods for the quantification of bacterial sulphate reduction in coastal marine sediments. I. Measurements with radiotracer technıque. Geomicrobiol. J. 1. 11-28

Jorgensen, B. B. (1982). Mineralization of organic matter in the sea bed - the role of sulphate reduction. Nature, Lond 296: 643-645

Jørgensen, B. B. (1983). Processes at the sediment-water interface. In: Bolin, B., Cook, R. B. (eds.) The major 
biogeochemical cycles and their interactions. John Wiley, Chichester, p. 477-509

Jorgensen, B. B., Bang, M., Blackburn, T. H. (1990). Anaerobic mineralization in marine sediments from the Baltic Sea North Sea transition. Mar Ecol. Prog. Ser 59: 39-54

King, G. M. (1988). Patterns of sulfate reduction and the sulfur cycle in a South Carolina salt marsh. Limnol. Oceanogr 33: $376-390$

King, G. M., Howes, B. L., Dacey, J. W. H. (1985). Short-term endproducts of sulfate reduction in a salt marsh: formation of acid volatile sulfides, elemental sulfur, and pyrite. Geochim. Cosmochim. Acta 49: 1561-1566

Kristensen, E., Andersen, F. $\varnothing$. (1987). Determination of organic carbon in marine sediments: a comparison of two CHN-analyzer methods. J. exp. mar. Biol. Ecol. 109: 15-23

Kristensen, E., Andersen, F. Ø., Kofoed, L. H. (1988). Preliminary assessment of benthic community metabolism in a south-east Asian mangrove swamp. Mar. Ecol. Prog. Ser. 48: $137-145$

Limpsaichol, P. (1978). Reduction and oxidation properties of the mangrove sediment, Phuket Island, Southern Thailand. Phuket mar Biol. Ctr Res. Bull. 23: 1-13

Luther III, G. W., Giblin, A., Howarth, R. W., Ryans, R. A (1982). Pyrite and oxidized iron mineral phases formed from pyrite oxidation in salt marsh and estuarine sediments. Geochim. Cosmochim. Acta 46: 2665-2669

Mackin, J. E., Swider, K. T. (1989). Organic matter decomposition pathways and oxygen consumption in coastal marine sediments. J. mar. Res. 47:681-716

Neilson, M. J., Richards, G. N. (1989). Chemical composition of degrading mangrove leaf litter and changes produced after consumption by mangrove crab Neosarmatium smithi (Crustacea: Decapoda: Sesarmidae). J. chem. Ecol. 4: $1267-1283$

Odum, W. E., Heald, E. J. (1975). The detritus-based food web of an estuarine mangrove community. In: Cronin, L. E.

This article was submitted to the editor (ed.) Estuarine research. Academic Press, New York, p. 265-286

Parsons, T R., Maita, Y., Lalli, C. M. (1984). A manual of chemical and biological methods for seawater analysis. Pergamon Press, Oxford

Rice, D. L., Tenore, K. R. (1981). Dynamics of carbon and nitrogen during the decomposition of detritus derived from estuarine macrophytes. Estuar. coast. Shelf Sci. 13: 681-690

Robertson, A. I. (1986). Leaf-burying crabs: their influence on energy flow and export from mixed mangrove forests (Rhizophora spp.) in northeastern Australia. J. exp. mar. Biol. Ecol. 102: 237-248

Skyring, G. W. (1987). Sulfate reduction in coastal ecosystems. Geomicrobiol. J. 5: 295-374

Swider, K. T., Mackin, J. E. (1989). Transformation of sulfur compounds in marsh-flat sediments. Geochim. Cosmochim. Acta 53: 2311-2323

Sørensen, J., Jargensen, B. B. (1987). Early diagenesis in sediments from Danish coastal waters: microbial activity and $\mathrm{Mn}-\mathrm{Fe}-\mathrm{S}$ geochemistry. Geochim. Cosmochim. Acta 51: $1583-1590$

Talling, F. (1973). The application of some electrochemical methods to the measurement of photosynthesis and respiration in fresh water. Freshwat. Biol. 3: 335-362

Thode-Andersen, S., Jargensen, B. B. (1989). Sulfate reduction and the formation of ${ }^{35} \mathrm{~S}$-labelled $\mathrm{FeS}, \mathrm{FeS}_{2}$, and $\mathrm{S}^{\circ}$ in coastal sediments. Limnol. Oceanogr. 34: 793-806

Troelsen, H., Jorgensen, B. B. (1982). Seasonal dynamics of elemental sulfur in two coastal sediments. Estuar. coast Shelf Sci. 15: 255-266

Twilley, R. R., Lugo, A. E., Patterson-Zucca, C. (1986). Litter production and turnover in basin mangrove forests in southeast Florida. Ecology 67: 670-683

Woodroffe, C. D. (1985). Studies of a mangrove basin, Tuff Crater, New Zealand: III. The flux of organic and inorganic particulate matter Estuar coast Shelf Sci 20: 447-461

Manuscript received: December 3, 1990

Revised version accepted: March 28, 1991 